\title{
Trajectory matching of ozonesondes and MOZAIC measurements in the UTLS - Part 1: Method description and application at Payerne, Switzerland
}

\author{
J. Staufer ${ }^{1, *}$, J. Staehelin ${ }^{1}$, R. Stübi ${ }^{2}$, T. Peter ${ }^{1}$, F. Tummon ${ }^{1}$, and V. Thouret ${ }^{3}$ \\ ${ }^{1}$ Institute for Atmospheric and Climate Science, ETH Zurich, Zurich, Switzerland \\ ${ }^{2}$ Federal Office of Meteorology and Climatology MeteoSwiss, Aerological Station, \\ Payerne, Switzerland \\ ${ }^{3}$ Laboratoire d'Aérologie, Université de Toulouse, CNRS, Toulouse, France \\ *now at: Laboratoire des Sciences du Climat et de l'Environnement, CEA-CNRS-UVSQ, IPSL, Gif-sur-Yvette, France \\ Correspondence to: J. Staufer (johannes.staufer@1sce.ipsl.fr)
}

Received: 2 June 2013 - Published in Atmos. Meas. Tech. Discuss.: 1 August 2013

Revised: 24 October 2013 - Accepted: 8 November 2013 - Published: 9 December 2013

\begin{abstract}
With the aim of improving ozonesonde observations in the upper troposphere/lower stratosphere (UTLS), we use three-dimensional forward and backward trajectories, driven by ERA-Interim wind fields to match and compare ozonesonde measurements at Payerne (Switzerland) with observations from the MOZAIC aircraft program from 19942009. The uncertainties associated with the sonde-MOZAIC match technique were assessed using "self-matches", i.e. matches of instruments of the same type, such as MOZAICMOZAIC. Despite strong vertical gradients of ozone at the tropopause, which render the match approach difficult, the method provides excellent results, showing mean differences between different MOZAIC aircraft of $\pm 2 \%$ (typically with a few hours between the up- and downstream match points). Matches between MOZAIC aircraft and Payerne ozonesondes show an agreement of $\pm 5 \%$ for sondes equipped with electrochemical concentration cells (ECC) and between $<5 \%$ (not scaled to total ozone) and $<10 \%$ (scaled) for the Brewer-Mast (BM) sondes after 1998. Prior to 1998 , BM sondes show an offset of around $20 \%$ (scaled). No break can be identified through the change from the BM to ECC sonde types in September 2002. A comparison of BM sondes with ozone measurements from the NOXAR B747 project for the period 1995-1996 show a smaller offset of around $15 \%$ (scaled), which may indicate a small drift in the MOZAIC calibration.
\end{abstract}

\section{Introduction}

Ozone $\left(\mathrm{O}_{3}\right)$ in the upper troposphere/lower stratosphere (UTLS) is an important element of the climate system. Perturbations in the $\mathrm{O}_{3}$ distributions in this region have strongest impact on surface temperatures when they are introduced around the tropopause (Lacis et al., 1990; Forster and Shine, 1997). Furthermore, modeling studies project greenhousegas-induced cooling of the stratosphere and an acceleration of stratospheric circulation (Brewer-Dobson circulation) (e.g. Shepherd, 2008), which could, in addition to the recovery of the $\mathrm{O}_{3}$ layer due to declining halogen abundances, significantly increase extra-tropical UTLS $\mathrm{O}_{3}$ over the 21st century (Hegglin and Shepherd, 2009). The documentation of possible long-term changes in UTLS $\mathrm{O}_{3}$ is therefore vital, but the complex dynamics and chemistry of the UTLS mean that observations need to have high vertical and horizontal spatial resolution, as well as high temporal resolution, to allow good comparison with numerical simulations.

Different in-situ techniques for measuring UTLS $\mathrm{O}_{3}$ concentrations, such as balloon-borne ozonesondes, are available. Although originally designed for measuring $\mathrm{O}_{3}$ for large-scale stratospheric dynamical studies (e.g. Smit, 2002), they have become invaluable for measuring changes in the vertical distribution of $\mathrm{O}_{3}$. In particular, their high vertical resolution provides observations of the pronounced vertical ozone gradients in the UTLS. A typical sonde ascent rate is about $4-6 \mathrm{~m} \mathrm{~s}^{-1}$ leading to an altitude resolution

Published by Copernicus Publications on behalf of the European Geosciences Union. 
of $100-200 \mathrm{~m}$. The low $\mathrm{O}_{3}$ concentrations below the tropopause, however, remain challenging. Special emphasis needs to be placed on data quality and consistency, since every sounding is made with a new instrument and a number of modifications, such as the use of different sensor types and radiosondes, or changing preflight or post flight data processing procedures, may have affected ozonesonde records (Smit et al., 2007).

Representative, high quality in-situ $\mathrm{O}_{3}$ measurements can also be obtained from regular aircraft measurements, for example, from the MOZAIC programme (Measurements of ozone, water vapour, carbon monoxide and nitrogen oxides by in-service Airbus aircraft, Marenco et al., 1998; Thouret et al., 1998a, b, 2006). The MOZAIC programme, in operation since August 1994, equipped commercial airliners with an accurate UV photometer to measure ozone concentrations. Cruise altitude of the aircraft range between $9-13 \mathrm{~km}$, coinciding with tropopause heights at mid-latitudes. Recently, MOZAIC has become a part of the IAGOS (In-service Aircraft for a Global Observing System, http://www.iagos.org) programme. IAGOS observations additionally include cloud droplets (number and size) and optionally either $\mathrm{CO}_{2}$ and $\mathrm{CH}_{4}$, aerosols, $\mathrm{NO}_{\mathrm{x}}$ or $\mathrm{NO}_{\mathrm{y}}$. Long-term, global scale observations will be provided by a fleet of 10-20 long-range inservice aircraft operated by several international airlines.

Regular aircraft measurements of ozone and nitrogen oxides were also provided by the NOXAR (Nitrogen Oxides and Ozone along Air Routes project) programme using a Swissair B747 as a measuring platform (Brunner et al., 2001) in 1995-1997.

To assess the performance and quantify systematic differences between different types of ozonesondes and ozonesondes from different manufacturers, the environmental simulation facility at the Juelich Research center was established as the World Meteorological Organization's (WMO) World Calibration Center for ozonesondes (Smit et al., 2007). The facility allows simulation of flight conditions of ozone soundings up to $35 \mathrm{~km}$ by controlling pressure, temperature and $\mathrm{O}_{3}$ concentrations. Up to four soundings can be simultaneously compared with an accurate UV-photometer. Detailed specifications of the environment chamber capabilities and measurements have been described by Smit et al. (2000, 2007).

Experiments performed during the Juelich Ozone Sonde Intercomparison Experiment (JOSIE 1996-2000, Smit and Kley, 1998; Smit and Straeter, 2004a, b; Smit et al., 2007) show that ECC (Electrochemical concentration cell) sondes have a positive bias of 5-10\% compared to the UV photometer, at conditions corresponding to $5-15 \mathrm{~km}$. Some dependence on preflight preparation, manufacturer, electrochemical sensing solution strength, and data processing was also observed (Smit et al., 2007). Conversely, the BM (Brewer-Mast) sondes show a negative bias of $-3 \%$ at altitudes between $5-15 \mathrm{~km}$, but a much higher scatter (Smit and Kley, 1998).
Generally, uncertainties of simulation chamber results are determined by randomly selecting sondes either from stocks or directly from the manufactures or the sounding sites. However, results may not necessarily reflect their performance under operational field conditions (Smit and Kley, 1998). A different approach was used by Bodeker et al. (1998), who applied a Monte Carlo error analysis to estimate the overall uncertainties of ECC sondes. They derived an uncertainty of 5-10\% at mid-latitude tropopause altitudes, depending on sonde manufacturers. Earlier intercomparison of ozonesondes with an UV photometer (e.g. Hilsenrath et al., 1986) estimated measurement accuracies of $10 \%$ in the troposphere and $5 \%$ in the stratosphere up to $10 \mathrm{hPa}$.

The quality of the ozonesonde time series' is, however, problematic. This is especially the case when data from the UTLS are used for long-term trend analysis, given the high variability in this region. Furthermore, the use of data may also strongly depend on data selection criteria, for example, criteria with respect to the correction factor (CF) (Logan et al., 1999). By comparing UTLS ozone climatologies with measurements from the 1970s commercial aircraft Global Atmospheric Sampling Programme (GASP) and MOZAIC observations from the 1990s, Schnadt Poberaj et al. (2009) showed that the irregular behaviour of the European BM sondes led to differences in the long-term changes of ozone over Europe. Recently, Logan et al. (2012) compared monthlymean time series' from European sounding sites with time series' from both neighbouring Alpine surface measurements and MOZAIC observations at nearby airports. They report large biases between MOZAIC and the BM sondes from 1994-1996 in the free troposphere, and conclude that "BM sonde data are not useful for deriving reliable tropospheric trends prior to about 1998".

The aim of this paper is to examine the feasibility of using trajectory analysis to allow systematic comparisons of $\mathrm{O}_{3}$ soundings with commercial aircraft measurements at altitudes between $4-14 \mathrm{~km}$, and to compare both instrument types over the entire period for which MOZAIC observations are available. Since both these types of ozone measurements are commonly used to investigate short- and longterm ozone changes (e.g. Tarasick et al., 2005; Thouret et al., 2006; Schnadt Poberaj et al., 2009; Logan et al., 2012), as well as to validate chemistry climate models, and remotesensing instruments (e.g. Law et al., 2000; Brunner et al., 2003; Liu et al., 2006), it is crucial to understand the degree of consistency between both datasets.

We make use of the "MATCH technique", an approach that matches two sets of observations by searching for air parcels sampled by both observations over the course of a few days using particular match criteria. Conceptually, this approach is derived from the MATCH technique applied to estimate ozone loss rates in the Arctic polar vortex (Rex et al., 1998; Morris et al., 2005, and references therein). A similar concept is "trajectory hunting", as used by Danilin et al. (2000, 2002a, b), which refers to the fact 
that trajectories originating from one platform are "hunted" for matches by other observation platforms.

This approach can be applied to any ozonesonde series provided that enough commercial aircraft measurements are available for comparison. For this work we use ozonesonde data from Payerne, Switzerland, to serve as an introduction and test of this method. Typically, 2-3 ozonesondes per week are launched at Payerne and in September 2002 BM sondes were replaced by ECC sondes. In this paper, we assess the reliability and consistency of the Payerne ozonesonde time series, checking and evaluating the data with MOZAIC measurements for the eight years available before and after the BM-ECC transition. In Staufer et al. (2013), the same method is applied to other ozonesonde sites.

\section{Methodology and measurements}

\subsection{Ozone measurements from regular aircraft}

\subsubsection{MOZAIC}

The MOZAIC programme, which begun in 1994, was established to obtain a large experimental data base of ozone and water vapour observations utilising automatic instruments installed on five commercial long-range Airbus airliners (Marenco et al., 1998). The ozone instrument is described in detail by Thouret et al. (1998a). Here we briefly summarise the main aspects. The MOZAIC ozone analysers are dualbeam UV absorption instruments from Thermo Environment. They have a response time of $4 \mathrm{~s}$, a detection limit of $2 \mathrm{ppbv}$, and an accuracy of $\pm 2 \%$. The uncertainty has been estimated at $\pm\left[2 \%+2\right.$ ppbv]. For $\mathrm{O}_{3}=100 \mathrm{ppbv}$, this means an uncertainty of \pm 4 ppbv. Quality assurance and control procedures have not changed since 1994 and involve a periodical (about 12 months) laboratory calibration with a reference analyser at the National Institute of Standards and Technology, in France, as well as an in-flight check with a built-in ozone generator to detect any drift in instrument efficiency.

The MOZAIC data used here were downloaded in March 2010. At this time data were available until March 2009 and comprised 31534 flights from August 1994 to March 2009. We used data integrated over $1 \mathrm{~min}$. At cruise altitude, which approximately coincides with tropopause altitude in the mid-latitudes $(9-13 \mathrm{~km})$, this corresponds to a horizontal resolution of about $15 \mathrm{~km}$.

\subsubsection{NOXAR}

Within the framework of the Swiss NOXAR (Nitrogen Oxides and Ozone along Air Routes) project (Brunner et al., 2001) a commercial airliner (B-747-357 Combi operated by Swissair) was equipped with a fully automated system (ECO PHYSICS CLD 780 TR) for measuring $\mathrm{NO}, \mathrm{NO}_{2}$, and $\mathrm{O}_{3}$ in the Northern Hemisphere UTLS. Measurements were made from May 1995 to May 1996 and from August to Novem- ber 1997, when the NOXAR airliner participated in the European POLINAT-2 (Pollution from Aircraft Emissions in the North Atlantic Flight Corridor) project.

Similar to MOZAIC, the ozone analyser uses the UVabsorption of $\mathrm{O}_{3}$ at $253.7 \mathrm{~nm}$. The response time of the analyser is $4 \mathrm{~s}$ with a total accuracy of $\pm 6 \%$ (Dias-Lalcaca et al., 1998). NOXAR data were obtained from the $E T H$ meg database (http://www.megdb.ethz.ch), from which $2 \mathrm{~min}$ averages are available (Brunner et al., 2003). One quasisimultaneous flight of MOZAIC and NOXAR aircraft over the North Atlantic on 20 December 1995 revealed excellent agreement for the observed range of $\mathrm{O}_{3}$ concentrations between 40 and 400 ppbv (Dias-Lalcaca et al., 1998).

\subsection{Ozone measurements from balloon-borne ozonesondes}

\subsubsection{Measurement principles}

Several types of ozonesondes have been developed, two of which have coexisted over the last $40 \mathrm{yr}$ and which are still in use: the BM sonde (Brewer and Milford, 1960) and the ECC sonde (Komhyr, 1969). Although the measurement principle of both electrochemical sonde types is similar - namely the titration of $\mathrm{O}_{3}$ in a potassium iodide (KI) sensing solution at present, the ECC sonde type dominates the global monitoring network, since they are less sensitive to preflight preparations and manufacturing aspects than BM sondes (Smit and Kley, 1998). Overall errors and uncertainties in the soundings are thought to originate from the background current of electrochemical cells, degrading of the pump efficiency with lower ambient pressures and inaccurate pump temperature measurements. Whereas the degrading of the pump efficiency predominantly affects the upper part of the profile, the background current produces the largest deviation below the tropopause and in the tropical troposphere when $\mathrm{O}_{3}$ concentration is low. The background signal depends strongly on the sonde preparation, especially for ECC sondes (e.g. Vömel and Diaz, 2010).

\subsubsection{Data processing methods at Payerne}

The BM sondes at Payerne were prepared and processed following WMO (World Meteorological Organization) standardized operating procedures (SOP), as described by Claude et al. (1987). However, the pump temperature was set to $280 \mathrm{~K}$ instead of $300 \mathrm{~K}$ because the packages specially designed for the Swiss meteorological sondes did not protect the BM pump in the same way as the original BM-VIZ packages (Jeannet et al., 2007; Stuibi et al., 2008). The SOP include scaling the whole profile to a near-by independent total ozone measurement which reduces the sonde variability and corrects for the low bias of the BM's ozone column. The procedure also requires an estimation of the $\mathrm{O}_{3}$ column above burst altitude. Its application to tropospheric 
$\mathrm{O}_{3}$ measurements has been debated (e.g. SPARC/IOC/GAW, 1998; De Backer et al., 1998; Thouret et al., 1998a), since the scaling depends primarily on stratospheric $\mathrm{O}_{3}$ and the assumptions made to estimate the ozone column above burst altitude. Any errors in the column measurement therefore can be carried over into the whole profile, in particular since (unscaled) BM sondes tend to underestimate ozone in the stratosphere more strongly than in the UTLS (see Stübi et al., 2008, their Fig. 8).

The total ozone normalization at Payerne is based on daily averages from Dobson spectrophotometer measurements at Arosa (200 km east of Payerne, $1860 \mathrm{~m}$ a.s.l.), or, if Dobson data are not available, on satellite measurements (Jeannet et al., 2007). For the calculation of the correction factor the height difference between Payerne and Arosa is taken into account using only ozonesonde measurements above the Arosa height. Strong horizontal ozone gradients between Payerne and Arosa can occasionally occur, but are expected to cancel out in the mean values (see also Jeannet et al., 2007).

Arosa total ozone columns, together with many other ground-based Dobson stations, have recently been used by Labow et al. (2013) for comparison with reprocessed SBUV, BUV and SBUV-2 data. Typically, their time series' agree within $1 \%$ over the past $40 \mathrm{yr}$ (see, for example, their Figs. 6 and 7). Over the last decade, the bias even approaches zero.

Since September 2002, ECC ozonesondes (model type ENSCI-2Z, $0.5 \%$ KI half-buffered sensing solution) have been operated at Payerne. The preparation and processing of the ECC sondes is described in detail by Stübi et al. (2008). Essentially, the background current is measured at ground level prior to launch and is assumed to be constant during the ascents. The thermistor for measuring pump temperature during flight is placed inside the Teflon block close to the piston. The pump efficiency correction was selected according to the manufacturer's recommendations (Komhyr et al., 1995). ECC sondes are usually not scaled to column ozone.

\subsection{Comparison method}

This study is based on the concept of identifying air masses which have been sampled for $\mathrm{O}_{3}$ measurements by both ozonesondes and MOZAIC aircraft. For our comparison, the signal of the ozonesonde, ozone partial pressure, is converted to molecule number density using pressure information from the radiosonde. Longitude and latitude position along the balloon flight track are usually not reported to archives, hence, we reconstruct the balloon's pathway if wind speed and direction were reported. If unavailable, a purely vertical ascent was assumed. For each launch we calculate the thermal tropopause defined as the lowest height of an at least $2 \mathrm{~km}$ thick layer, in which the temperature lapse rate $\Gamma=-\partial T / \partial z$ is less than $2 \mathrm{~K} \mathrm{~km}^{-1}$ (World Meteorological Organization, 1957). Subsequently, we define the UTLS as the region centred $\pm 125 \mathrm{hPa}$ around the local tropopause. Beginning from the bottom of the UTLS up to its top, fully three-dimensional trajectories (both forward and backward) are initialised at $5 \mathrm{hPa}$ intervals from the bottom to the top of the UTLS using the trajectory tool LAGRANTO (Wernli and Davies, 1997) to trace the air masses in each direction for $144 \mathrm{~h}$ (6 days).

LAGRANTO has performed well in several other studies focusing on the UTLS (e.g. Wernli and Bourqui, 2002; Cui et al., 2009). For our study, it is driven by 6 hourly wind fields from ECMWF's ERA-Interim reanalysis with a horizontal resolution of $1^{\circ}$ longitude $\times 1^{\circ}$ latitude and 61 hybrid vertical levels. Although there are several numerical models with better spatio-temporal resolution, we use ERA-Interim to ensure that the results are independent of changes in the underlying model. The temporal index for the tracing output is set to one minute to be consistent with MOZAIC observations.

Trajectories are then searched for matches with MOZAIC using match criteria that specify the maximum horizontal and vertical distance between trajectory and aircraft. Potential temperature $\Theta$ is used for the vertical distance. See below for the match criteria used.

Matches are of different quality since trajectory errors typically accumulate with time (i.e. the further the aircraft observation is in time from the ozonesonde observation). A weighting is therefore introduced to account for the reduced accuracy of the trajectories. Along each trajectory we collect all MOZAIC observations satisfying the match criteria, calculate the weighted mean and compare it to the point measurement of the sonde at initialization of the trajectory. We use the time lag between the MOZAIC observations and the sounding for the weights, giving more weight to MOZAIC observations that are closer to the soundings. Thus, for each trajectory the weighted mean $\bar{y}$ is calculated according to

$\bar{y}=\frac{\sum_{i=1}^{M} w_{i} y_{i}}{\sum_{i=1}^{M} w_{i}}$,

where $M$ is the number of matches along one trajectory. $w_{i}$ is the weight of the individual aircraft observation $y_{i}$ and is obtained by

$w_{i}=\frac{\left|t^{*}-\Delta t\right|}{t^{*}}$,

where $t^{*}$ is the duration of the trajectories, $144 \mathrm{~h}$, and $\Delta t$ the time lag between aircraft observation and the sonde.

We assume that $\mathrm{O}_{3}$ behaves as a passive tracer for the duration of the trajectories. This is a critical assumption, but justified because the lifetime of $\mathrm{O}_{\mathrm{x}}$ in the free troposphere varies from days to months, depending on season and ambient $\mathrm{NO}_{\mathrm{x}}$ concentrations (Liu et al., 1987). In the lower stratosphere the photochemical lifetime is even longer, i.e. several months. Any trajectories that descend or ascend more than $450 \mathrm{hPa}$ within six or less days are excluded. This excludes deep stratospheric intrusions and avoids sampling polluted air masses transported in warm conveyor belts. Such 

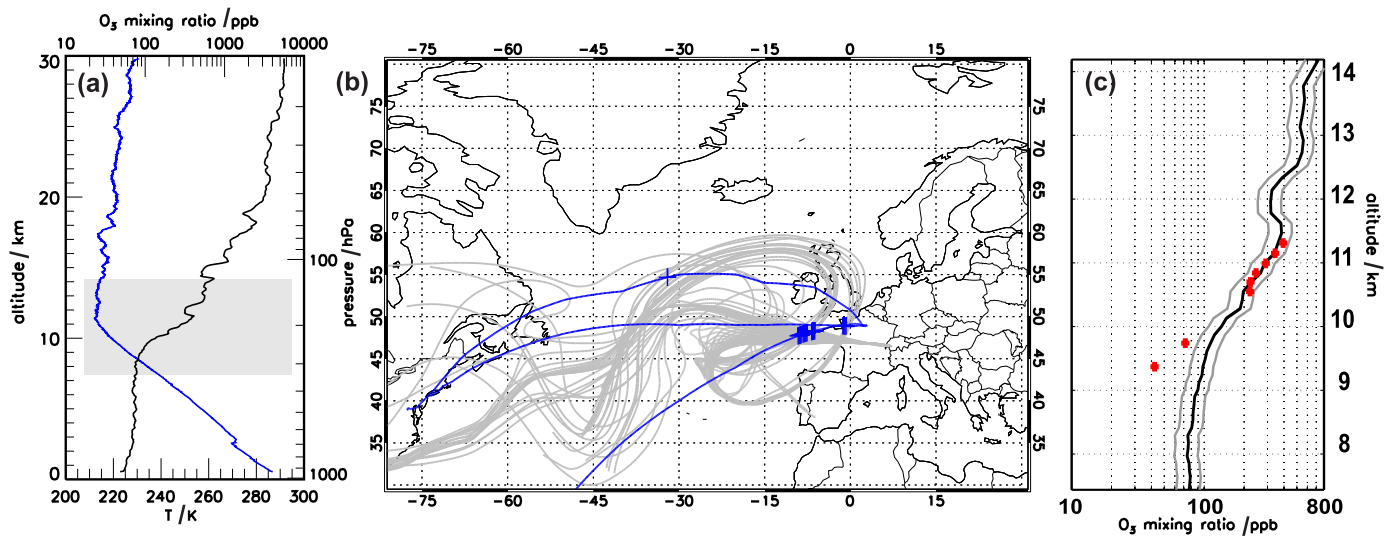

Fig. 1. (a) Ozone (black) and temperature (blue) profiles measured at Payerne on 18 April 1995. The gray area indicates the UTLS ( $\pm 125 \mathrm{hPa}$ above and below the tropopause). (b) Plot of the 6 day backward trajectories. The blue solid lines denote the flight paths of three MOZAIC aircraft for which matches were found. Matches are denoted by blue plus signs. (c) UTLS $\mathrm{O}_{3}$ as a function of altitude, as observed by the sonde. Gray solid lines denote the $20 \%$ uncertainty range of the soundings. Each red dot denotes the weighted mean $(\bar{y})$ of the aircraft observations along respective trajectories.

air parcels likely mix strongly with surrounding air, resulting in changes to the air parcels' chemical composition (Stohl, 2001). Roughly $6 \%$ of all trajectories calculated for each sounding site are dismissed by this criterion.

Finally, we bin all data as a function of a vertical coordinate (e.g. altitude, pressure, $\Theta$ or relative to tropopause height, see below) measured by the sonde at the initialization of the trajectories. If a certain bin contains more than one matched trajectory from the same sounding, the median of all sonde-MOZAIC differences (median of all $\bar{y}$ 's) is used. For the statistical analysis, each sounding contributes at most one specific value to a bin.

Morris et al. (2000) and Danilin et al. (2002b) suggested combining forward and backward trajectories to compensate for possible changes in $\mathrm{O}_{3}$ along the trajectories due to mixing or chemistry. To this end, double matches of the kind "Airbus-sonde-Airbus" would be useful, i.e. an aircraft observation (not necessarily the same aircraft) upstream and downstream of the sonde. Unfortunately, few such matches were obtained (94 out of 3924 matched trajectories, or, $2 \%$ ). However, we have ample matches upstream and (separately) downstream. Although they are analysed independently, both contribute their median differences to each altitude bin. In this sense, we attempt to statistically compensate for differences between the unidirectional trajectories (which typically differ by $5 \%$ ).

The same method is also applied to "self-compare" ozone measurements from different MOZAIC flights, thus providing an indication of the uncertainty of the matching technique introduced by trajectory errors and the finite matching criteria. Finally, we use NOXAR measurements to check the consistency of $\mathrm{O}_{3}$ observations between the two aircraft projects.

\section{Results}

\subsection{Illustration of method}

The method is illustrated in Fig. 1 for a BM sonde launched at 11:21 UTC at Payerne on 18 April 1995. The tropopause is at $10 \mathrm{~km}$ altitude, with a temperature of $218 \mathrm{~K}$, marking the transition into a nearly isothermal stratosphere. $\mathrm{O}_{3}$ increases sharply across the tropopause (Fig. 1a). Backward trajectories calculated from this Payerne ozonesonde launch match MOZAIC aircraft observations obtained over the Atlantic Ocean. Figure $1 \mathrm{~b}$ shows matches using a match area with radius $r=75 \mathrm{~km}$ in the horizontal, and potential temperature difference $\Delta \Theta= \pm 0.6 \mathrm{~K}$ in the vertical (see Sect. 3.2). The weighted mean (see Eq. 1) is calculated for each trajectory and compared to the ozone sounding measurements at initialization of the respective trajectory (Fig. 1c). Measurements above $10 \mathrm{~km}$ agree fairly well, whereas the two points below show pronounced differences. The aircraft observations for these two points are found over western France (around $40 \mathrm{ppbv}$ ) and southeast of Greenland (around $70 \mathrm{ppbv}$ ), respectively. This result indicates that matches in the troposphere are more difficult than those above the tropopause, a topic that is investigated in more detail below.

\subsection{Optimization of match criteria}

To find appropriate matching criteria values and to obtain an estimate of the accuracy of the matching approach, we carry out a "self-match", i.e. applying the analysis to data from the same instrument. Danilin et al. (2002b) termed this test "selfhunting". Zero differences would be expected if the trajectories were noise-free, the observed species is a passive tracer, and if the uncertainties of the measurements were negligible. 


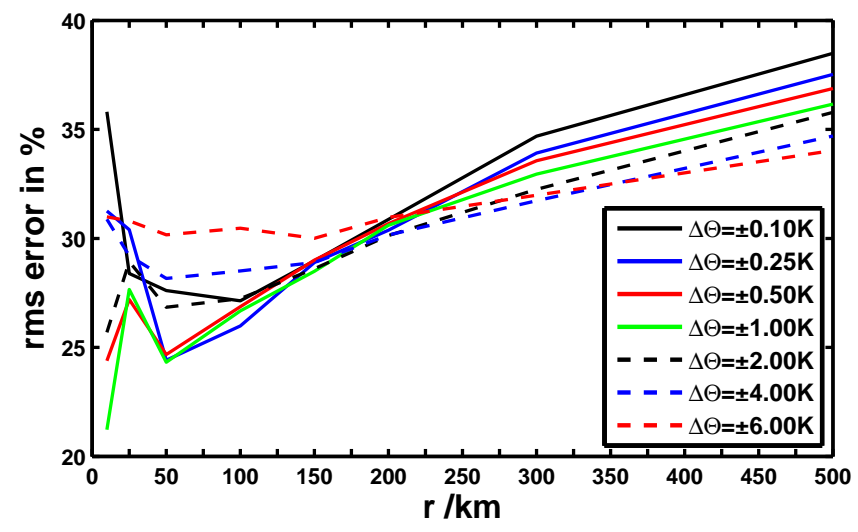

Fig. 2. Statistical uncertainty (RMSE) of the trajectory matching technique as a function of match criteria, $\Delta \Theta$ and $r$, averaged over all matched backward trajectories as deduced from MOZAICMOZAIC self-matches (see text for details).

Every $60 \mathrm{~min}$, we initialize 6 day backward trajectories from every MOZAIC aircraft flight path between 4$13 \mathrm{~km}$ altitude for the year 2000, which is the year with most MOZAIC flights. In contrast to the comparison with ozonesondes, here we also allow matches outside of the $\pm 125 \mathrm{hPa}$ pressure difference from the local tropopause. For our analysis we use only trajectories originating between 30 and $60^{\circ} \mathrm{N}$, and only matches between two different aircraft are allowed. For each trajectory we gradually increased the horizontal match radius $r$ and the vertical criterion $\Delta \Theta$, the difference in potential temperature between trajectory and aircraft. The root-mean-square of the relative ozone differences (RMSE) is calculated for a set of trajectories and plotted in Fig. 2 as function of $r$ for different $\Delta \Theta$. The RMSE reaches a minimum of $25 \%$ at around $50-100 \mathrm{~km}$ for $\Delta \Theta=0.25-1 \mathrm{~K}$ and gradually increases with increasing $r$ and $\Delta \Theta$. This value is substantially larger than the errors found by Rex et al. (1998), since their study considers only stratospheric air masses whereas our study also encompasses the more dynamically varying tropopause region. An error of $25 \%$ still, however, appears to be reasonable given the pronounced vertical and horizontal $\mathrm{O}_{3}$ gradients in the UTLS. For $r<50 \mathrm{~km}$ and $\Delta \Theta<0.25 \mathrm{~K}$, the small sample size prevents drawing concise conclusions, since outliers are heavily weighted in the RMSE calculation. Optimal matching criteria are therefore $r=50-100 \mathrm{~km}$ and $\Delta \Theta=0.25-1 \mathrm{~K}$. The comparison is rather robust with respect to the exact match criteria. As shown in Fig. 3, the median of the relative differences as well as the corresponding error bars show a very similar pattern and no statistically significant difference could be identified at the $10 \%$ level (90\% confidence). Match criteria of $\Delta \Theta \leq \pm 0.6 \mathrm{~K}$ and $r \leq 75 \mathrm{~km}$ are chosen for the comparison of aircraft and ozonesondes. Furthermore, we also dismiss all matched trajectories where the weighted (Eq. 2) standard deviation of the matches along a trajectory is $\geq 10 \%$. We attribute such large variability to either mixing

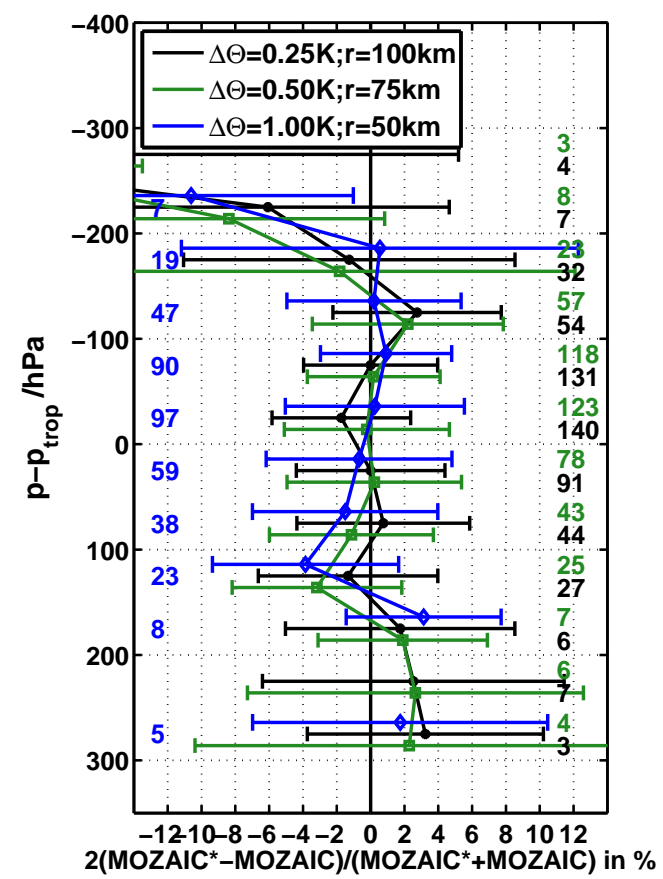

Fig. 3. Quality of MOZAIC self-matches depending on match criteria. Differences are grouped into $50 \mathrm{hPa}$ bins from the tropopause pressure at 2 PVU obtained at initialization of the trajectories. The horizontal bars show the $90 \%$ confidence interval of the median of the relative differences. Numbers denote the number of matched trajectories per bin. MOZAIC* denotes the ozone concentration at initialization of the trajectories. Symbols are slightly shifted to prevent overlap.

along the trajectory, errors in their locations or ozone laminae in the profile that remain unresolved in the 1 min aircraft observations. Using these criteria excludes around $6 \%$ of the matched trajectories from the statistical analysis.

\subsection{Testing consistency of trajectory matches}

Figure $4 \mathrm{a}$ and $\mathrm{b}$ reports the results of a self-matching test for 6 day trajectories launched in January, April, July and October 2000 and from January to December 2001 as function of altitude and scaled to the tropopause. Since the height of the thermal tropopause cannot be calculated from MOZAIC aircraft observations, we apply a dynamical definition of the tropopause at $2 \mathrm{PVU}$ (potential vorticity unit, $1 \mathrm{PVU}=$ $10^{-6} \mathrm{~m}^{2} \mathrm{~s}^{-1} \mathrm{~K} \mathrm{~kg}^{-1}$, obtained from ERA-Interim fields). In addition to data for the year 2001, four months from 2000 are used to represent all four seasons and to increase sample size. The error bars in Fig. 4a encompass the $0 \%$ line at all altitude layers, except in the middle troposphere, where the number of matches was small. The vast majority of matched trajectories originate between $10-12 \mathrm{~km}$ altitude, i.e. at cruise level in the mid-latitudes. Below $10 \mathrm{~km}$ altitude the sample size is much smaller. Above $10 \mathrm{~km}$, the mean of the relative differences is around $0 \%$, however, in contrast, below 


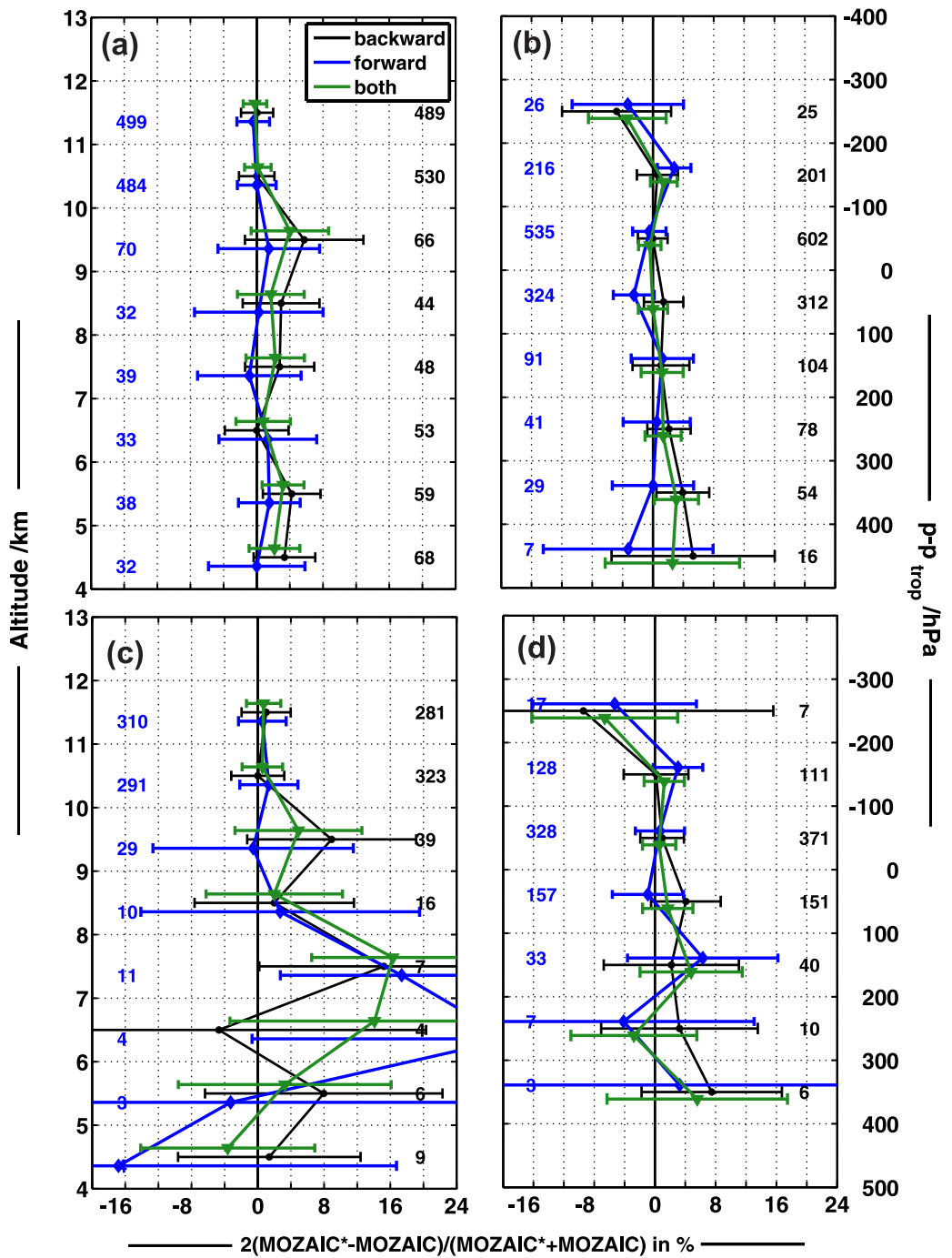

Fig. 4. Upper panels (a and b): Sensitivity analysis of self-matching results based on 6 day trajectories for MOZAIC observations. Difference using only backward trajectories (black), difference using only forward trajectories (blue) and combination of both, forward- and backward trajectories (green). Differences are grouped in $1 \mathrm{~km}$ wide altitude layers (a). Differences grouped in $100 \mathrm{hPa}$ bins from the tropopause pressure at 2 PVU (b). Horizontal bars indicate the $90 \%$ confidence interval of the median of the relative differences. Black and blue numbers show the number of matched backward and forward trajectories per bin, respectively. MOZAIC* denotes the ozone concentration at initialization of the trajectories. Symbols are shifted to prevent overlap. Lower panels (c and d): same as in (a) and (b), but excluding matches from the first $24 \mathrm{~h}$ of each trajectory.

$10 \mathrm{~km}$, the mean relative differences range between $2-4 \%$. These noisier levels may be attributable to the higher sensitivity of the match criteria lower down in the troposphere, to the smaller sample size and to lower ozone concentrations. There are small differences between the application of forward and backward trajectories, which are on the order of $2-8 \%$ at lower levels below $10 \mathrm{~km}$ altitude, but which are statistically insignificant. The bias of one instrument vs. another is slightly higher for backward than forward trajectories, possibly indicating that ozone production occurs in the sampled air masses.
For both forward and backward trajectories, the mean time between a match and the starting point of a trajectory is $11 / 2$ days. This time is shorter than for matches with most sounding sites. We therefore also check results from selfmatching test against the length of the trajectories. Figure $4 \mathrm{c}$ and d shows the results after eliminating all matches within the first $24 \mathrm{~h}$ of each trajectory. Results are smoother when they are relative to tropopause pressure, since the representation as a function of geometric altitude suffers from having only very few matches in the lower four bins, and thus a correspondingly large statistical uncertainty. As expected, the exclusion of the first $24 \mathrm{~h}$ leads to substantially larger 

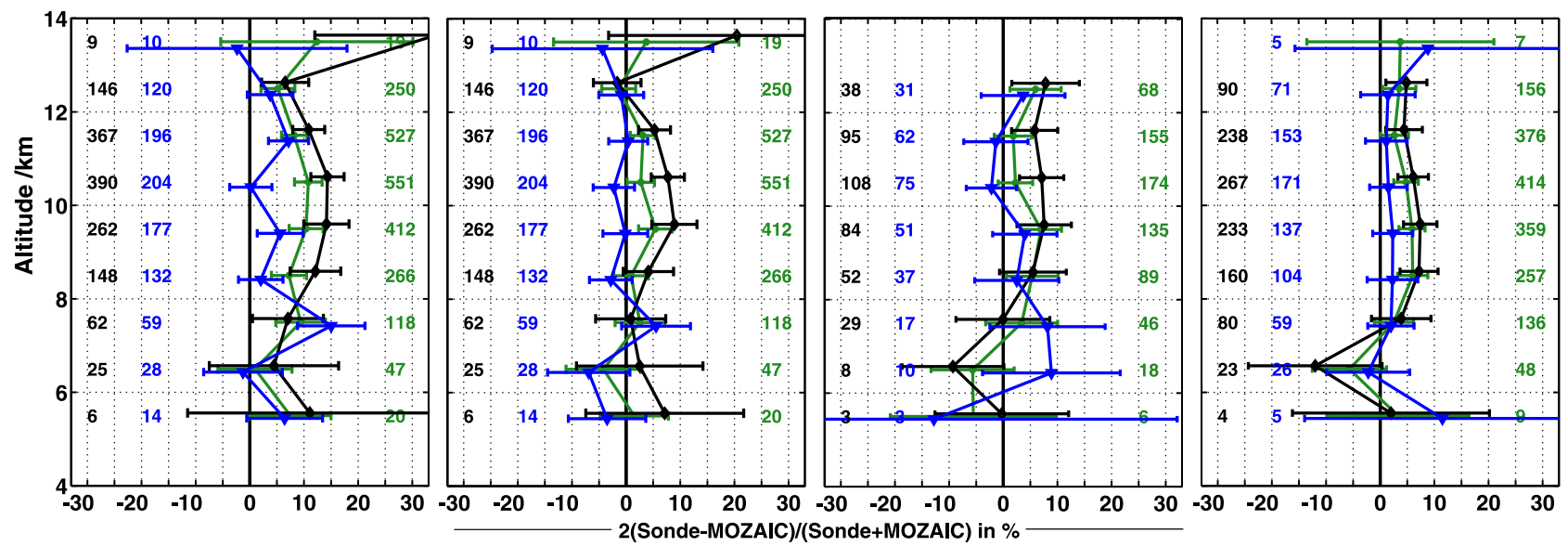

Fig. 5. Median of the relative differences from 6 day trajectories between Payerne ozonesondes and MOZAIC $\mathrm{O}_{3}$ measurements averaged over the period 1994-2009. Black: difference using backward trajectories. Blue: difference using forward trajectories. Green: difference using both forward and backward trajectories. Differences are grouped into $1 \mathrm{~km}$ altitude bins. Horizontal bars: $90 \%$ confidence interval of the median, with number of soundings $(N)$ per bin. Only data with $N>2$ are displayed. The symbols are slightly shifted vertically for clarity. (First column) Both, BM and ECC profiles are scaled to Arosa ozone column measurements. (Second column) No column scaling is applied. (Third column) Only 1 day trajectories are used and sondes not scaled to ozone column. (Fourth column) as for third column but with four additional trajectories each displaced by $0.5^{\circ}$ in latitude and longitude from the central trajectory's starting position (see text).

error bars at low altitudes (i.e. below $9 \mathrm{~km}$ altitude or below $200 \mathrm{hPa}$ from the tropopause) since trajectory errors typically increase with the trajectory length (Stohl, 1998) and because of the significantly reduced sample size. We therefore exclude these altitudes by limiting the UTLS to $\pm 125 \mathrm{hPa}$ from the tropopause. This reduces the differences between either including or not including the $24 \mathrm{~h}$ to $\pm 3 \%$. The evidence provided here suggests that three-dimensional trajectories produced using the ERA-Interim reanalysis are suitable for linking different instrumentation platforms to validate ozone measurements. As a result of the larger uncertainty seen in the UTLS when using this technique, a fairly large sample size is required to compensate for statistical errors.

\subsection{Comparison of the Payerne ozone soundings with MOZAIC (1994-2009)}

The method outlined above allows the determination of average ozone profile differences between the UV photometer technique employed by MOZAIC and the routinely flown ozonesondes at Payerne. It also allows a comprehensive analysis of the performance of the ozonesondes over different periods, including changes in sensor types, and an evaluation of the influence of different data processing methods.

The overall mean differences for 1994-2009 are presented in Fig. 5 as a function of sounding altitude at initialization of the trajectories. In total, 1220 soundings can be compared with MOZAIC, i.e. $55 \%$ of the 2247 sondes launched at Payerne between August 1994 and March 2009. Most matches are obtained from trajectories that originate between altitudes of $8-12 \mathrm{~km}$. Figure 6 shows the spatial distribution of the matches for Payerne summed up over a $3^{\circ} \times 3^{\circ}$ grid, with

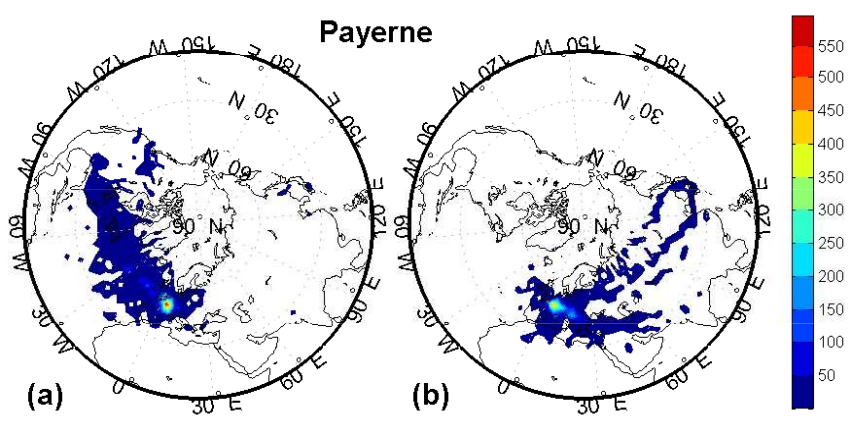

Fig. 6. Spatial distribution of matches of MOZAIC aircraft observations with (a) backward trajectories and (b) forward trajectories initialized at Payerne. The colour bar shows the total number of matches summed up over a $3^{\circ} \times 3^{\circ}$ grid.

most matches found over Western and Central Europe. This feature is also reflected in the temporal distribution of the matches, with the majority of matches occurring within the first two days. The geographical distribution of forward and backward trajectory matches differs. The highest number of matches, however, lie to the west of Switzerland for both forward and backward trajectories.

On average, the soundings measure $10 \%$ higher ozone mixing ratios than the UV photometers employed by MOZAIC. This value could be reduced to $5 \%$ if the scaling of the whole profile to the Arosa ozone column was not applied (Fig. 5). The differences between forward and backward trajectories are $5-10 \%$, which is substantially higher than expected from the MOZAIC self-matching test. The ozonesondes are significantly higher compared to MOZAIC 


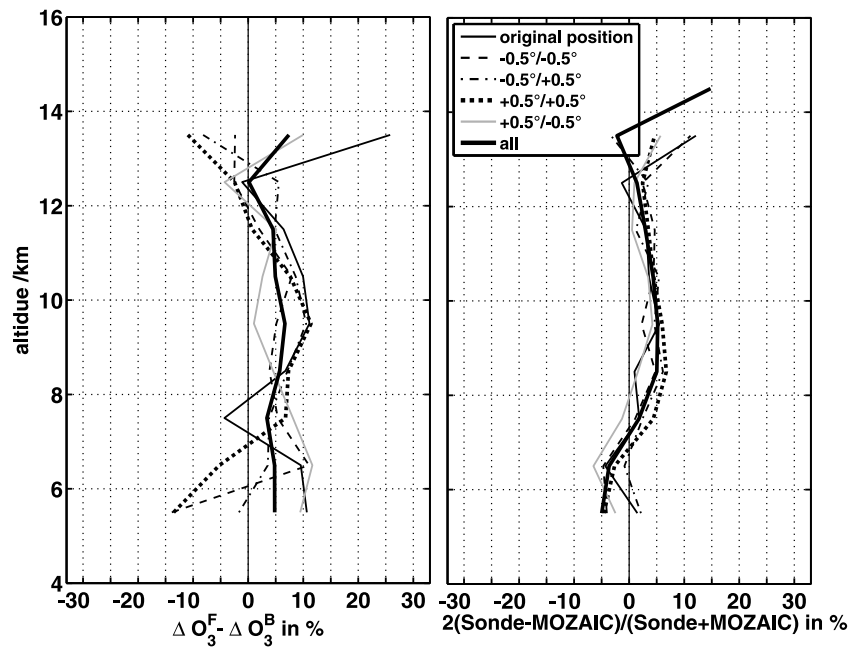

Fig. 7. Sensitivity of relative $\mathrm{O}_{3}$ differences with respect to trajectory starting position. Line style shows position (see insert). (a) Differences in $\Delta \mathrm{O}_{3}$ when either only forward $\left(\Delta \mathrm{O}_{3}{ }^{\mathrm{F}}\right)$ or only backward trajectories $\left(\Delta \mathrm{O}_{3}{ }^{\mathrm{B}}\right)$ are used. (b) Mean deviations between sonde and MOZAIC using both forward and backward trajectories.

when just back trajectories are used, suggesting that $\mathrm{O}_{3}$ is produced along the trajectories, and thus violating the assumption of $\mathrm{O}_{3}$ being a passive tracer. However, an offset, although less, is still present in case of 1 day trajectories, a period with much reduced $\mathrm{O}_{3}$ production (Fig. 5c).

\subsubsection{Sensitivity analysis}

Wind speed and direction are not always available at every pressure level for each sounding and thus the reconstructed path of the balloon ascent path may not necessarily be correct. The starting positions of the trajectories may therefore be poorly defined, or possibly wrong in space and/or time. In addition, the spatio-temporal interpolation from the regular numerical model grid to the actual trajectory position can also be critical for complex flows (Stohl et al., 1995). Hence, as sensitivity analysis, four additional trajectories are calculated for every trajectory starting position, each displaced by $0.5^{\circ}$ latitude and longitude from the central trajectory's starting position. We initialize these surrounding trajectories with the same $\mathrm{O}_{3}$ concentrations as the central trajectory. The sensitivity to the different trajectory starting positions in terms of differences in $\Delta \mathrm{O}_{3}$ obtained from backward-only and forward-only trajectories is shown in Fig. 7a. Although the differences in $\Delta \mathrm{O}_{3}$ between the unidirectional trajectories amount to $10 \%$ in particular altitude bins (Fig. 7a), the results using combined trajectories are very robust and give similar $\Delta \mathrm{O}_{3}$ profiles (Fig. $7 \mathrm{~b}$ ). Below $9 \mathrm{~km}$ the results are more sensitive to the starting positions as a result of both the smaller ozone concentrations and smaller sample size in the troposphere, in particular below $7 \mathrm{~km}$. Furthermore, the results from the combined method are hardly affected by the

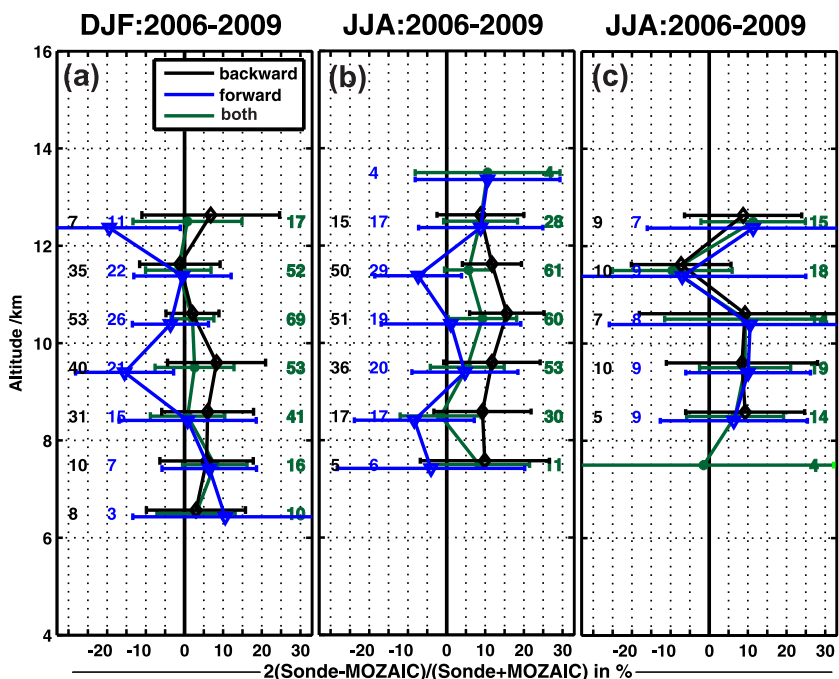

Fig. 8. Similar to Fig. 5. Results for 2006-2009 are plotted using 6 day trajectories for (a) DJF and (b) JJA, as well as using 1 day trajectories for (c) JJA. Sonde profiles are scaled to an independent ozone column.

use of either 1 day or 6 day trajectories (Fig. 5d) emphasising its robustness with respect to the length of the trajectories. For the rest of this analysis we use all trajectories (the central point plus the four displaced trajectories) because of the robust results of combined trajectories, the better agreement between forward and backward trajectories in both the 1 day and the 6 day case, and the larger sample size. The sample size now comprises 1899 sondes, $83 \%$ of the sondes launched at Payerne during MOZAIC's operational phase (1994-2009).

Figure 8 shows $\Delta \mathrm{O}_{3}$ profiles as a function of altitude for winter and summer averaged over the period 20062009. Backward trajectories systematically indicate that the ozonesondes have a higher bias to MOZAIC for both seasons, typically on the order of $5 \%$. For most bins the differences are, however, statistically insignificant. The largest offset between forward and backward trajectory directions is obtained in summer, and is also more pronounced at lower altitudes (reaching up to $15-20 \%$ ). This is qualitatively consistent with tropospheric summer smog chemistry along the 6 day trajectories in the troposphere, since the 1 day trajectories do not show a large offset between the two directions (Fig. 8c). The differences are, however, too large to be explained solely by photochemistry, given the rates of ozone photochemistry in the troposphere. In addition, other factors such as when and where the measurements take place (e.g. before or after a frontal zone, after/before a trough/high) also likely contribute to the observed differences. 

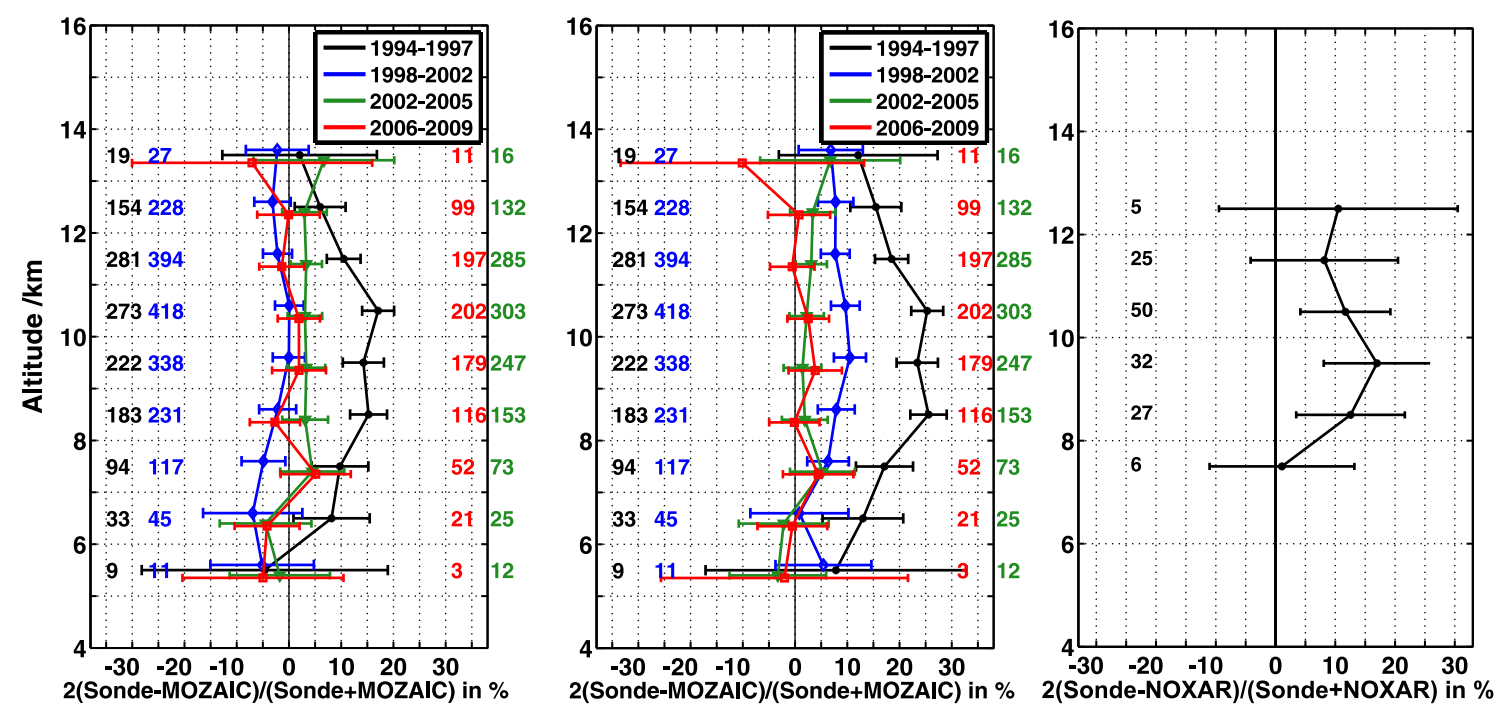

Fig. 9. As for Fig. 5 but results are separated for 4 different periods. Only BM sondes were used for the periods 1994-1997 and 19982002, whereas only ECC sondes were launched during the two later periods (2002-2006 and 2006-2009). BM and ECC sondes before normalization (left panel). Normalized BM and ECC sondes (centre panel). Median of the relative differences between scaled BM sondes and NOXAR O 3 measurements averaged over the period 1995-1997 (right panel).

\subsubsection{Analysis of the time series}

Figure 9 shows the average difference profile for four different periods using the combined forward and backward trajectories data set: two periods before changing from BM to ECC sondes and two periods after the change. Before 1998, $\mathrm{BM}$ sondes exceed MOZAIC up to $25 \%$, or up to $15 \%$ if data are not scaled to the Arosa column ozone. The explanation for this offset is still unclear. Schnadt Poberaj et al. (2009) and Logan et al. (2012) report similar deviations in the 1990s for European BM sondes in the free and upper troposphere. After 1998, however, this large offset is significantly reduced with BM sondes underestimating MOZAIC by $<5 \%$, if not normalized. Scaling to column ozone can correct for the very low bias, but the mean differences increase to $5-10 \%$. The fact that scaling of BM sondes changes the sign of the bias has also been noted by De Backer et al. (1998) and Stübi et al. (2008). De Backer et al. (1998) also proposed an alternative normalization procedure, which was evaluated by Lemoine and De Backer (2001) against SAGEII data. Generally, the scaling has been introduced to correct for the low bias of the BM sondes' column, but this clearly has a strong impact on UTLS ozone measurements. BM-ECC dual flights at Payerne during the OZEX campaign (Stübi et al., 2008) showed that (unscaled) BM sondes underestimate ozone compared to ECC sondes by approximately $5-8 \%$ in the UTLS, and by $12-15 \%$ in the stratosphere (15$25 \mathrm{~km}$ ). Since a single scaling factor, which depends primarily on the stratospheric ozone content, is applied to the whole profile, the higher bias of the BM sondes in the stratosphere is carried over into the UTLS. Thus, if scaling is applied to BM sondes, some portion of $\Delta \mathrm{O}_{3}$ certainly arises from higher biases of the BM sondes in the stratosphere. The differences in the $\Delta \mathrm{O}_{3}$ between 1994-1998 and 1998-2002, however, cannot be explained by the scaling, which is around 1.10 for both periods.

The ECC mean difference profiles between the two periods are rather similar, both showing mean deviations < $5 \%$ (ECC overestimate MOZAIC), in accordance with the JOSIE results (Smit et al., 2007). The normalization does not strongly affect the ECC performance since the correction factor typically is around 1.0.

The time series of relative differences are plotted in Fig. 10 for both normalized data and unnormalized data, respectively. For each sounding we calculate the mean relative difference per $1 \mathrm{~km}$ bin and average over all bins to produce monthly means. Finally, a 13 month central moving average is applied to smooth the time series. In general, the time series' reproduce the above findings: there is a large offset between BM sondes and MOZAIC's UV-photometers prior to $1997 / 1998$, which then decreases to $< \pm 10 \%$ after this date, while the mean ECC sonde deviations typically drift around the $0 \%$ line (Fig. 10c). The backward trajectories reveal a typical positive offset of below 5\%, except for 2006 when the sondes underestimate MOZAIC by $5 \%$. The dip in 2006 is more pronounced using forward-only trajectories and continues into 2008 .

\subsection{Comparison of the Payerne soundings with NOXAR measurements}

The reason for the large offset between BM sondes and MOZAIC prior to $1997 / 1998$ remains unexplained. 

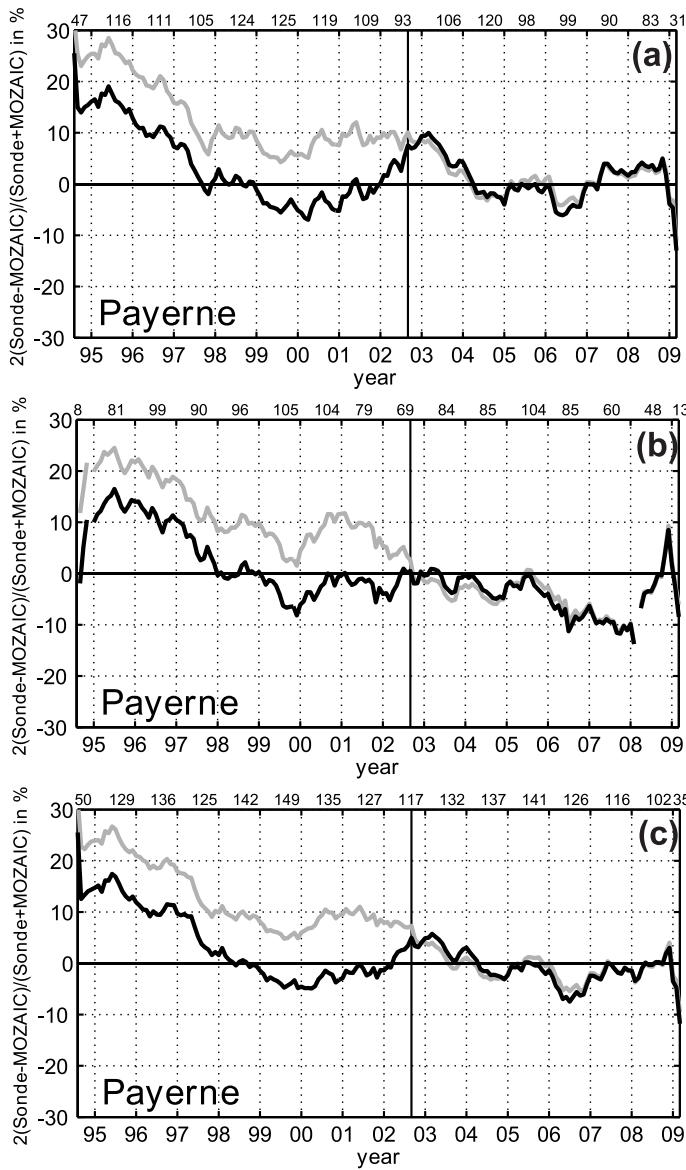

Fig. 10. Times series of the relative differences between sondes and MOZAIC averaged from 4-14 km altitude, using (a) only backward trajectories, (b) only forward trajectories and (c) combining forward and backward trajectories. Numbers at the top denote the number of soundings available per year. Gray lines indicate both BM and ECC sondes scaled. The vertical black solid line denote the change from BM to ECC sondes in September 2002.

Logan et al. (2012), however, found an increase in the MOZAIC bias from 1994-2009 over Frankfurt/Munich compared with the alpine surface site Zugspitze. To investigate this further, we assume NOXAR measurements as a reference dataset. We use the same method for comparing BM sondes at Payerne with NOXAR as we used for the MOZAIC comparison. Figure 9c shows that the mean deviation between sonde (scaled to column ozone) and NOXAR are around $10-15 \%, 5 \%$ lower than the comparison with MOZAIC. The fact that some different ozonesondes are possibly included in the NOXAR comparison should not affect the comparability. However, because of the much smaller sample size, the sonde-NOXAR comparison has much larger uncertainties. The analysis comprises 56 soundings in 1995, 30 in 1996 and only 8 in 1997. Despite the large uncertainty, this somewhat surprising results may indicates that the large offset between MOZAIC and BM sondes prior to 1998 may possibly be partially attributable to a drift in the MOZAIC calibration. The results seem to be qualitatively consistent with Logan et al. (2012). However, a large part of the temporal change in the difference between BM ozonesondes and MOZAIC remains. Note, Dias-Lalcaca et al. (1998) reported an excellent agreement between MOZAIC and NOXAR based on a quasi-simultaneous flight-by-flight comparison. However, their analysis is based on just one simple flight and therefore lacks representativeness.

\section{Summary and conclusions}

In this paper, we test the application of trajectories for comparing different ozone measurement platforms in the upper troposphere/lower stratosphere, such as electrochemical ozonesondes and MOZAIC aircraft observations. Trajectories are driven by ERA-Interim reanalysis wind-fields, ensuring that the model used has not undergone changes in resolution or parameterizations over the period considered, August 1994 to March 2009.

By comparing MOZAIC with MOZAIC ("selfmatching"), we found that the trajectory method produces reasonable results showing mean differences of $\pm 2 \%$ between different aircraft, which is considered accurate enough for our purposes. Uncertainties associated with individual trajectories are larger in the UTLS than in the stratosphere, thus, for reliable comparison larger sample sizes are required. Small differences between the results from backward-only and forward-only trajectories provide an indication of the uncertainty associated with this technique, especially when applied to a station close to the Alps, and the difficulties models and trajectories have to accurately quantify the meteorological conditions in the UTLS. The assumption of $\mathrm{O}_{3}$ being a passive tracer along the duration of 12 days is critical, especially in the troposphere in summer.

Application of the match technique to Payerne ozonesonde data show encouraging agreement with MOZAIC aircraft observations after 1998. The mean differences of ECC sonde type are less than $\pm 5 \%$, independent of scaling. The BM sondes record from 1998-2002 shows a similar bias but if scaling to total ozone is applied this increases to up to $10 \%$. Concerning the homogeneity of the time series with respect to MOZAIC, the forward-only case shows that BM sondes agree with the ECC sondes when they are not scaled to column ozone. The pattern obtained from the backward-only case is more difficult to interpret since the ECC sonde differences amount to $10 \%$ in the first years of operation. In general, however, the homogeneity of the times series seems to be better preserved if no scaling is applied which is different to findings of Stübi et al. (2008) who recommend scaling both sonde types.

Recently Logan et al. (2012) reported that BM sondes only produced reliable measurements in the troposphere after 1998. When we use NOXAR instead of MOZAIC 
measurements, mean differences between sonde and aircraft are roughly $5 \%$ smaller over the $1995-1997$ period. This suggests a possible drift in the MOZAIC calibration, consistent with the findings of Logan et al. (2012). This drift, however, cannot entirely explain the large differences between sonde and MOZAIC observations observed before 1998.

Payerne was chosen as a test site for this method since it is a very well documented sounding station and we could confirm our results with previous publications. In a companion paper (Staufer et al., 2013), results from many other ozonesonde stations are discussed. Sites include Sodankylä (Northern Finland) and Scoresbysund (Greenland), both of which are far away from any MOZAIC airport and thus trajectories are essential to compare the different observation platforms. We aim to provide a coherent overview of the performance of the various ozonesonde sites and to evaluate the reliability and consistency of their records in the UTLS which is vital because different sonde types, sensors, preparation and processing procedures have been used and/or have changed.

Acknowledgements. J. Staufer's search was funded by a MeteoSwiss GAW-CH grant. The authors warmly acknowledge the European Commission, Airbus, CNRS-France, and FZJ-Germany for their strong support of the MOZAIC project and the airlines (Lufthansa, AirFrance, Austrian, Air Namibia, and former Sabena) who have carried the MOZAIC instrumentation free of charge since 1994. MOZAIC is presently funded by INSU-CNRS (France), Météo-France, CNES, Université Paul Sabatier (Toulouse, France) and Research Center Jülich (FZJ, Jülich, Germany). IAGOS is additionally funded by the EU projects IAGOS-DS, IAGOS-ERI, and IGAS. MOZAIC-IAGOS data are available via the CNES/CNRSINSU Ether web-site http://www.pole-ether.fr. Ozonesonde data used in this publication were obtained from the World Ozone and Ultraviolet Radiation Data Center (WOUDC, located in Toronto and operated by Environment Canada; publicly available at http://www.woudc.org) and were downloaded between March and April 2010. We are grateful to the soundings team at Payerne, who carefully prepare and perform all the launches. Finally, thanks are also due to Swiss International Air Lines, successor of SwissAir, for fruitful collaboration within the NOXAR project.

Edited by: S. Godin-Beekmann

\section{References}

Bodeker, G. E., Boyd, I. S., and Matthews, W. A.: Trends and variability in vertical ozone and temperature profiles measured by ozonesondes at Lauder, New Zealand: 1986-1996, J. Geophys. Res., 103, 28661-28681, 1998.

Brewer, A. and Milford, J.: The Oxford Kew ozonesonde, P. Roy. Soc. Lond., 256, 470-495, doi:10.1098/rspa.1960.0120, 1960.

Brunner, D., Staehlin, J., Jeker, D., Wernli, H., and Schumann, U.: Nitrogen oxides and ozone in the tropopause region of the Northern Hemisphere: measurements from commercial aircraft in 1995/1996 and 1997, J. Geophys. Res., 106, 27673-27699, 2001.

Brunner, D., Staehelin, J., Rogers, H. L., Köhler, M. O., Pyle, J. A., Hauglustaine, D., Jourdain, L., Berntsen, T. K., Gauss, M., Isaksen, I. S. A., Meijer, E., van Velthoven, P., Pitari, G., Mancini, E., Grewe, G., and Sausen, R.: An evaluation of the performance of chemistry transport models by comparison with research aircraft observations - Part 1: Concepts and overall model performance, Atmos. Chem. Phys., 3, 1609-1631, doi:10.5194/acp-31609-2003, 2003.

Claude, H., Hartmannsgruber, R., and Köhler, U.: Measurement of Atmospheric Ozone Profiles Using the Brewer/Mast Sonde - Preparation, Procedure, Evaluation, WMO Global Ozone Research and Monitoring Project, 17, World Meteorol. Organ., Geneva, Switzerland, 1987.

Cui, J., Sprenger, M., Staehelin, J., Siegrist, A., Kunz, M., Henne, S., and Steinbacher, M.: Impact of stratospheric intrusions and intercontinental transport on ozone at Jungfraujoch in 2005: comparison and validation of two Lagrangian approaches, Atmos. Chem. Phys., 9, 3371-3383, doi:10.5194/acp-9-33712009, 2009.

Danilin, M. Y., Santee, M. L., Rodriguez, J. M., Ko, M. K. W., Mergenthaler, J. M., Kumer, J. B., Tabazadeh, A., and Livesey, N. J.: Trajectory hunting: a case study of rapid chlorine activation in December 1992 as seen by UARS, J. Geophys. Res., 105, 40034018, 2000.

Danilin, M. Y., Ko, K. W., Bevilacqua, R. M., Lyjak, L. V., Froidevaux, L., Santee, M. L., Zawodny, J. M., Hoppel, K. W., Richard, E. C., Spackman, J. R., Weinstock, E. M., Herman, R. L., McKinney, K. A., Wennberg, P. O., Eisele, F. L., Stimpfle, R. M., Scott, C. J., Elkins, J. W., and Bui, T. V.: Comparison of ER-2 aircraft and POAM III, MLS, and SAGE II satellite measurements during SOLVE using traditional correlative analysis and trajectory hunting technique, J. Geophys. Res., 107, 8315, doi:10.1029/2001JD000781, 2002a.

Danilin, M. Y., Ko, M. K. W., Froidevaux, L., Santee, M. L., Lyjak, L. V., Bevilacqua, R. M., Zawodny, J. M., Sasano, Y., Irie, H., Kondo, Y., Russell III, J. M., Scott, C. J., and Read, W. G.: Trajectory Hunting as an effective technique to validate multiplatform measurements: analysis of the MLS, HALOE, SAGE-II, ILAS and POAM-II data in October-November 1996, J. Geophys. Res., 107, 4420, doi:10.1029/2001JD002012, 2002b.

De Backer, H., De Muer, D., and De Sadelaer, G.: Comparison of ozone profiles obtained with Brewer-Mast and Z-ECC sensors during simultaneous ascents, J. Geophys. Res., 103, 1964119648, 1998.

Dias-Lalcaca, P., Brunner, D., Imfeld, W., Moser, W., and Staehelin, J.: An automated system for the measurement of nitrogen oxides and ozone concentrations from a passenger aircraft: instrumentation and first results of the project NOXAR, Environ. Sci. Technol., 32, 3228-3236, 1998.

Forster, P. M. D. F. and Shine, K. P.: Radiative forcing and temperature trends from stratospheric ozone changes, J. Geophys. Res., 102, 10841-10855, 1997.

Hegglin, M. I. and Shepherd, T. G.: Large climate-induced changes in ultraviolet index and stratosphere-to-troposphere ozone flux, Nat. Geosci., 2, 687-691, 2009.

Hilsenrath, E. W., Attmannspacher, W., Bass, A., Evans, W., Hagemeyer, R., Barnes, R. A., Komhyr, W., Mauersberger, K., 
Mentall, J., Proffitt, M., Robbins, D., Taylor, S., Torres, A., and Weinstock, E.: Results from the balloon ozone intercomparison campaign (BOIC), J. Geophys. Res., 91, 13137-13152, 1986.

Jeannet, P., Stübi, R., Levrat, G., and Staehelin, J.: Ozone balloon soundings at Payerne (Switzerland): reevaluation of the time series 1967-2002 and trend analysis, J. Geophys. Res., 112, D11302, doi:10.1029/2005JD006862, 2007.

Komhyr, W. D.: Electrochemical concentration cells for gas analysis, Ann. Geophys., 25, 203-210, 1969,

http://www.ann-geophys.net/25/203/1969/.

Komhyr, W. D., Barnes, R. A., Brothers, G. B., Lathrop, J. A., and Opperman, D. P.: Electrochemical concentration cell ozonesonde performance evaluation during STOIC 1989, J. Geophys. Res., 100, 9231-9244, 1995.

Labow, G. J., McPeters, R. D., Bhartia, P. K., and Kramarova, N.: A comparison of 40 years of SBUV measurements of column ozone with data from the Dobson/Brewer network, J. Geophys. Res. Atmos., 118, 7370-7378, doi:10.1002/jgrd.50503, 2013.

Lacis, A. A., Wuebbles, D. J., and Logan, J. A.: Radiative forcing of climate by changes in the vertical distribution of ozone, J. Geophys. Res., 95, 9971-9981, 1990.

Law, K. S., Plantevin, P.-H., Thouret, V., Marenco, A., Asman, W. A. H., Lawrence, M., Crutzen, P. J., Muller, J.F., Hauglustaine, D. A., and Kanakidou, M.: Comparison between global chemistry transport model results and Measurements of Ozone and Water Vapor by Airbus In-Service Aircraft (MOZAIC) data, J. Geophys. Res., 105, 1503-1525, 2000.

Lemoine, R. and De Backer, H.: Assessment of the Uccle ozone sounding time series quality using SAGE II data, J. Geophys. Res., 106, 14515-14523, doi:10.1029/2001JD900122, 2001.

Liu, S. C., Trainer, M., Fehsenfeld, F. C., Parrish, D. D., Williams, E. J., Fahey, D. W., Hübler, G., and Murphy, P. C.: Ozone production in the rural troposphere and the implications for regional and global ozone distributions, J. Geophys. Res., 92, 4191-4207, 1987.

Liu, X., Chance, K., Sioris, C. E., Kurosu, T. P., and Newchurch, M. J.: Intercomparison of GOME, ozonesondes, and SAGE II measurements of ozone: demonstration of the need to homogenize available ozonesonde data sets, J. Geophys. Res., 111, D14305, doi:10.1029/2005JD006718, 2006.

Logan, J. A., Megretskaia, I. A., Miller, A. J., Tiao, G. C., Choi, D., Zhang, L., Stolarski, R. S., Labow, G. J., Hollandsworth, S. M., Bodeker, G. E., Claude, H., De Muer, D., Kerr, J. B., Tarasick, D. W., Oltmans, S. J., Johnson, B., Schmidlin, F., Staehelin, J., Viatte, P., and Uchino, O.: Trends in the vertical distribution of ozone: a comparison of two analysis of ozonesonde data, J. Geophys. Res., 104, 26373-26399, 1999.

Logan, J. A., Staehelin, J., Megretskaia, I. A., Cammas, J.P., Thouret, V., Claude, H., De Backer, H., Steinbacher, M., Scheel, H.-E., Stübi, R., Fröhlich, M., and Derwent, R.: Changes in ozone over Europe: analysis of ozone measurements from sondes, regular aircraft (MOZAIC) and alpine surface sites, J. Geophys. Res., 117, D09301, doi:10.1029/2011JD016952, 2012.

Marenco, A., Thouret, V., Nédélec, P., Helten, M., Kley, D., Karcher, F., Simon, P., Law, K., Pyle, J., Poschmann, G., Von Wrede, R., Hume, C., and Cook, T.: Measurement of ozone and water vapour by Airbus in-service aircraft: the MOZAIC airborne program, an overview, J. Geophys. Res., 103, 2563125642, 1998 .
Morris, G. A., Gleason, J. F., Ziemke, J., and Schoeberl, M. R.: Trajectory mapping: a tool for validation of trace gas observations, J. Geophys. Res., 105, 17875-17894, 2000.

Morris, G. A., Bojkov, B. R., Lait, L. R., and Schoeberl, M. R.: A review of the Match technique as applied to AASE-2/EASOE and SOLVE/THESEO 2000, Atmos. Chem. Phys., 5, 2571-2592, doi:10.5194/acp-5-2571-2005, 2005.

Rex, M., von der Gathen, P., Harris, N. R. P., Lucic, D., Knudsen, B. M., Braathen, G. O., Reid, S. J., De Backer, H., Claude, H., Fabian, R., Fast, H., Gil, M., Kyrö, E., Mikkelsen, I. S., Rummukainen, M., Smit, H. G., Stähelin, J., Varotsos, C., and Zaitcev, I.: In situ measurements of stratospheric ozone depletion rates in the Arctic winter 1991/1992: a Lagrangian approach, J. Geophys. Res., 103, 5843-5853, 1998.

Schnadt Poberaj, C., Staehelin, J., Brunner, D., Thouret, V., De Backer, H., and Stübi, R.: Long-term changes in UT/LS ozone between the late 1970s and the 1990s deduced from the GASP and MOZAIC aircraft programs and from ozonesondes, Atmos. Chem. Phys., 9, 5343-5369, doi:10.5194/acp-9-53432009, 2009.

Shepherd, T. G.: Dynamics, stratospheric ozone, and climate change, Atmos. Ocean, 46, 117-138, doi:10.3137/ao.460106, 2008.

Smit, H. G. J.: Ozonesondes, in: Encyclopedia of Atmospheric Sciences, edited by: Holton, J., Pyle, J., and Curry, J., Academic Press, London, 1469-1476, 2002.

Smit, H. G. J. and Kley, D.: JOSIE: the 1996 WMO international intercomparison of ozonesondes under quasi flight conditions in the environmental simulation chamber at Jülich, WMO Global Atmos. Watch Rep., 130, World Meteorol. Organ., Geneva, Switzerland, 1998.

Smit, H. G. J. and Straeter, W.: JOSIE-1998, Performance of ECC Ozone Sondes of SPC-6A and ENSCI-Z Type, WMO Global Atmos. Watch Rep., 157, World Meteorol. Organ., Geneva, Switzerland, 2004a.

Smit, H. G. J. and Straeter, W.: JOSIE-2000, Jülich Ozone Sonde Intercomparison Experiment 2000, the $2000 \mathrm{WMO}$ international intercomparison of operating procedures for ECC-ozonesondes at the environmental simulation facility at Jülich, WMO Global Atmos. Watch Rep., 158, World Meteorol. Organ., Geneva, Switzerland, 2004b.

Smit, H. G. J., Sträter, W., Helten, M., and Kley, D.: Environmental simulation facility to calibrate airborne ozone and humidity sensors, Jül-Berichte, 3796, Forschungszentrum Jülich, Jülich, Germany, 2000.

Smit, H. G. J., Straeter, W., Johnson, B. J., Oltmans, S. J., Davies, J., Tarasick, D. W., Hoegger, B., Stubi, R., Schmidlin, F. J., Northam, T., Thompson, A. M., Witte, J. C., Boyd, I., and Posny, F.: Assessment of the performance of ECC-ozonesondes under quasi-flight conditions in the environmental simulation chamber: insights from the Juelich Ozone Sonde Intercomparison Experiment (JOSIE), J. Geophys. Res., 112, D19306, doi:10.1029/2006JD007308, 2007.

SPARC/IOC/GAW: Assessment of Trends in the Vertical Distribution of Ozone, edited by: Harris, N., Hudson, R., and Phillips, C., SPARC Report No. 1, WMO Ozone Research and Monitoring Project, Report 43, WMO, World Meteorol. Organ., Geneva, Switzerland, 1998. 
Staufer, J., Staehelin, J., Stübi, R., Peter, T., Tummon, F., and Thouret, V.: Trajectory matching of ozonesondes and MOZAIC measurements in the UTLS - Part 2: Application to the global ozonesonde network, Atmos. Meas. Tech. Discuss., 6, 70997148, doi:10.5194/amtd-6-7099-2013, 2013.

Stohl, A.: Computation, accuracy and applications of trajectories a review and bibliography, Atmos. Environ., 32, 947-966, 1998.

Stohl, A.: A 1-year Lagrangian "climatology" of airstreams in the Northern Hemisphere troposphere and lowermost stratosphere, J. Geophys. Res., 106, 7263-7279, 2001.

Stohl, A., Wotawa, G., Seibert, P., and Kromp-Kolb, H.: Interpolation errors in wind fields as a function of spatial and temporal resolution and their impact on different types of kinematic trajectories, J. Appl. Meteorol., 34, 2149-2165, 1995.

Stübi, R., Levrat, G., Hoegger, B., Viatte, P., Staehelin, J., and Schmidlin, F. J.: In-flight comparison of Brewer-Mast and electrochemical concentration cell ozonesondes, J. Geophys. Res., 113, D13302, doi:10.1029/2007JD009091, 2008.

Tarasick, D. W., Fioletov, V. E., Wardle, D. I., Kerr, J. B., and Davies, J.: Changes in the vertical distribution of ozone over Canada from ozonesondes: 1980-2001, J. Geophys. Res., 140, D02304, doi:10.1029/2004JD004643, 2005.

Thouret, V., Marenco, A., Logan, J. A., Nédélec, P., and Grouhel, C.: Comparisons of ozone measurements from the MOZAIC airborne program and the ozone sounding network at eight locations, J. Geophys. Res, 103, 25695-25720, 1998a.
Thouret, V., Marenco, A., Nédélec, P., and Grouhel, C.: Ozone climatologies at 9-12 km altitude as seen by the MOZAIC airborne program between September 1994 and August 1996, J. Geophys. Res, 103, 25653-25679, 1998 b.

Thouret, V., Cammas, J.-P., Sauvage, B., Athier, G., Zbinden, R., Nédélec, P., Simon, P., and Karcher, F.: Tropopause referenced ozone climatology and inter-annual variability (1994-2003) from the MOZAIC programme, Atmos. Chem. Phys., 6, 1033-1051, doi:10.5194/acp-6-1033-2006, 2006.

Vömel, H. and Diaz, K.: Ozone sonde cell current measurements and implications for observations of near-zero ozone concentrations in the tropical upper troposphere, Atmos. Meas. Tech., 3, 495-505, doi:10.5194/amt-3-495-2010, 2010.

Wernli, H. and Bourqui, M.: A Lagrangion "1-year climatologoy" of (deep) cross-tropopause exchange in the extratropical Northern Hermisphere, J. Geophys. Res., 107, 4021, doi:10.1029/2001JD000812, 2002.

Wernli, H. and Davies, H. C.: A Lagrangian-based analysis of extratropical cyclones. I: The method and some applications, Q. J. Roy. Meteorol. Soc., 123, 467-489, 1997.

World Meteorological Organization: WMO Bulletin, Vol. 6, World Meteorol. Organ., Geneva, Switzerland, 1957. 